\title{
Cultural Public Sphere: Tracking the Yogyakarta City Policy Agenda through the \#JogjaOraDidol Hashtag on Twitter
}

\author{
Ujang Fahmi•
}

\begin{abstract}
Instead of studying the virtual space using the Political Public Sphere concept, this study adopts the Literary Public Sphere point of view to examine and narrate the nature of a Cultural Public Sphere in social media. The researchers see interactivity in social media as an articulation of expression involving emotions and aesthetics (affective communication). Using the mixed method of Topic Modelling, Social Network Analysis (SNA), and Discourse Analysis in the case of the presence of the \#JogjaOraDidol hashtag in Twitter, this study conclude that the Cultural Public Sphere has three dimensions of Public Sphere as introduced by Dahlgren (2005). The dynamic of inclusivity for anyone to express themselves and to engage in public issues discussions indicates that space is inclusive not only because of the technical support of the media but also because of the commitment of its users (structural dimension). The emergence of three virtual communities (fans, artists and activists) that develop a collective identity represents a subset of the real local population and demonstrates the ideal role taking of the representational aspect of Public Sphere. The interactional one is indicated by the discourse constructed using reflexive but straightforward symbols represent the interaction between users and the meaning that users do to the contents of the media used. Meanwhile, the real action show of the discourse develops virtually does not entrap the user in pseudo-empowerment. As an implication, using specific parameter, notably the hashtag identifies a social movement, policymakers can use data from social media in the agenda-setting process. Additionally, in the context of \#JogjaOraDidol, soft data can also be used to evaluate the moratorium policy of granting the hotel's construction permit.
\end{abstract}

\section{Keywords:}

cultural public sphere; social media; e-policy cycle; topic modelling; sna; discourse analysis

\section{Introduction}

Social media is considered to be at the forefront of the development of public sphere (Dahlberg, 1998; Dahlgren, 2005; Etling, Roberts, \& Faris, 2014; Mergel, 2017; Papacharissi, 2002, 2009). This assumption is based on the role that social media can play in everyday life, such as being able to foster public opinion and a culture of participation (Lim, 2013c; Palen, 2008). Therefore, the concept of public sphere is often used in research involving cyberspace or social media. The cases are like a study conducted by Barlow (2008) in a study of blogs in America, Elting et al. (2014) about blogs in Russia, Mergel (2017) about the impact of social media, and Oblak (2002) who studied representation in cyberspace.

The use of the public sphere concept is also supported by previous research that shows that blogs and micro blogs have a social and political role. For example, social media can be used to coordinate social movements (Lim, 2012, 2013c, 2013a; Theocharis, 2013; van den Heerik, van Hooijdonk, Burgers, \& Steen,

\footnotetext{
- Data Scientist at Kedata Indonesia

Email: eppofahmi@gmail.com
} 
2017), campaigns (Metzgar \& Maruggi, 2009), and even revolution (Dhillon, 2014; Eltantawy \& Wiest, 2011; Mueller \& van Huellen, 2012). Not only that, blogs can also be used as one of the bottom up sources to find out public policy preferences (Ceron, 2017; Ceron \& Negri, 2016; Koltsova \& Koltcov, 2013). In fact, Kusumasari (2014) advises policy makers to learn the sound so that the policies taken get legitimacy.

On one hand, the research by using data from social media that is claimed by Severo et al. (2016) as soft data is easy to do. On the other hand, some previous studies that used data from social media and used the concept of public sphere had several weaknesses. In terms of theory, Dahlberg (2014) notes that there are at least three major weaknesses in research on public sphere on the internet or online; first, the weakness of the theory and specifications of public space as a critical conception. Second, the weak transition from definition to criteria that can be evaluated. Third, limited explanation; it relies too heavily on statistical generalization. In addition, weaknesses also exist from the side of the method used, where most of the research using soft data is carried out using count-based methods (Marwick, 2014).

In terms of methods, the use of a countbased approach on one hand is very convenient and makes it easier for researchers to process and extract information. The researcher can process and extract from data that is generally unstructured from social media. On the other hand, the method is considered to over-simplify the complexity of the lives of social media users, where according to Supeli (2010) social media users are prone to being trapped in pseudo empowerment, or salctivism (Lim, 2013c). Habermas (1991) define public sphere as space between the state and society. Castells (2008) also consider it as a community project aimed at the state, which has several requirements that must be fulfilled.

The requirement for a place to be referred to as public sphere includes being free from political and economic interests, being inclusive, and able to foster public opinion. In other words, the sphere must be discursive. In this context, Dahlgren (2005) argues that public sphere consists of three dimensions, namely structural, representational, and interactional dimensions. The structural dimension refers to the dynamics of inclusivity or exclusivity of public sphere. The representational dimension refers to the results of the structural dimension, namely the diversity of actors in it. The interactional dimension refers to the results of interactions between citizens and the media used, in other words citizens can reflect on what is in their environment.

The three dimensions of public space above have been used by Batorski et al. (2017) to review public space on Face-book Fan Pages. However, in research using quantitative mixed methods (social network analysis, hierarchical cluster analysis and linear regression), it cannot explain the higher activity of a community than other communities. Therefore, their allegations about the possible causes of such high activity, namely the low representation of community discourse in mainstream media, still need further research. In contrast, a study conducted by Brenne (2016) using a qualitative approach cannot provide evidence about one element of the representational dimension, namely the diversity that causes discursive sphere. More importantly, in general, the research on online public sphere uses the concept of political public sphere, while the literary concept or so-called cultural public sphere by McGuigan (2005) is rarely used.

Therefore, this study aims to narrate the existence of three dimensions of cultural public sphere as one of the sources of insight in the process of determining public policy agenda and evaluation using a mixed method between Text Mining, Social Network Analysis (SNA), and discourse analysis. The study was conducted on the existence of \#JogjaOraDidol hashtag on Twitter. It was based on preliminary 
observations of the hashtag, which has been used since 2013 in more than 16 thousand tweets sent by more than 7 thousand different users. The \#JogjaOraDidol hashtag was originally a slogan written in an art festival in accordance with the definition of cultural public sphere according to McGuigan (2005). He said that it is the sphere for political, public, and individual articulation contested through affective communication models (McGuigan, 2005). In addition, the hashtag used by citizens to criticize development policies and spatial management in the city of Yogyakarta tends to be consistently used compared to other similar tags, such as \#balinotforsale and \#savimpinsiliwangi.

The study of the existence of the \#JogjaOraDidol hashtag can be used as a view in two policy cycles, namely the agenda determination and policy evaluation. They are all including in a concept that is in accordance with the currently developing environment, and e-Policy Cycle. The e-Policy Cycle concept introduced by Höchtl (2016) aims to provide a bridge between public administration theory and the e-governance sector beyond the service approach that has dominated research on e-government. In other words, the studies conducted can provide new insights on how policy decisions can be made based on ICT and Big Data.

Specifically, the results of this study provide a new way of point of view at citizen participation in social media. It will later have implications for the use of data from social media in the process of determining agendas and conducting policy evaluations, where in general, agenda setting, as said by Sayre (Sayre, Bode, Shah, Wilcox, \& Shah, 2010) was carried out by looking at issues in the media that received a lot of public attention and understanding of decision makers. However, with the existence of social media that can stream and disseminate information more quickly, policymakers can monitor opinions formed in virtual space as views and its possibility to be used to see public acceptance of a policy (Ceron \& Negri, 2015).

This paper consists of several parts. The first part of the paper is the introduction, which is followed by a literature review related in the second part. Furthermore, the research method is explained and discussed in the third part. The fourth section displays the results and discussion of research findings. This article then concludes with a conclusion about cultural public sphere, theoretical and practical implications.

\section{Theoretical Framework \\ Public Sphere and e-Cycle Policy}

Public sphere is a space between society and the state (Habermas, 1991), through which sphere can control the government in an informal way, namely through public opinion (Curran, 1993). For that reason, public sphere is considered important in democratic life, because decision-making must be subject to rational and critical considerations from all affected parties (Calhoun, 2014; Dahlberg, 2007; Levasseur \& Carlin, 2001).

Calhoun (2014) in particular says that public sphere has three practical functions, namely to: (1) identify problems that are of concern to the community and its organization; (2) identify problems that are of common concern and solutions; and (3) ensure that public organizations can serve the public interest. Therefore, public sphere must be inclusive, free from political and economic interests, and enable the formation of public opinion (Habermas, 1991).

As a concept, public sphere is a dynamic concept, where in its development it is found various kinds of public sphere, such as the Black Public Sphere (Squires, 2002), Green Public Sphere (Heijden, 2010; Sima, 2011; Yang \& Calhoun, 2007 ), and Alternative Public Sphere (Dahlgren, 2005; Etling et al., 2014). The last concept is called directly referring to 
the development of information technology, including the existence of social media, where through social media as defined by Chen (2013), everyone has the same opportunity to be involved in public discussion. In other words, social media is an inclusive place. Dahlgren (2013) calls the internet to be at the forefront of the development of public sphere.

The development of the public sphere concept is driven by advances in information technology, especially the internet. It has brought optimism to make the policy-making process more deliberative. In this context, Höchtl (2016) introduces a policy cycle concept that he calls the e-policy cycle. The concept is an adaptation to bridge the intersection between the developing environment and the conventional policy cycle concept that can be seen in the figure 1.

Based on the policy cycle which stages can be seen in Figure 1 above, there is no significant difference. The only difference lies in the evaluation process, which in the concept of e-policy cycle is carried out continuously. The question is that, where is the role of social media? Specifically in explaining the concept, Höchtl (2016) mentions that data from social media can be used in the policy setting stage. In this stage, in addition to relying on their understanding of the environment and the problems that exist to define policy problems, policy makers generally need to see the mass media to find out issues that are of common concern and are considered important by the public (Sayre et al., 2010).

The problem is that mainstream media at this time sometimes cannot display all the news concerning public issues (Sayre et al., 2010). On the other hand, the trust in social media that is technically inclusive and allows everyone to leave a digital footprint, is also tarnished by irresponsible people who use it to, for example, spread hate speech (Lim, 2017b), and hoaxes (Beers, 2006). In this context the author agrees with Paparaschi (2009) who said that making the virtual sphere into a virtual public sphere is not only a technical feature of a media but also depends on the commitment of real people of the account owner. Some previous studies (See: Ceron \& Negri, 2015, 2016; Koltsova \& Koltcov, 2013) show that in certain contexts, blogs and micro blogs such as Twitter can be easy and be available data sources at all times to be used as one of the insights in mapping public policy preferences.

Figure 1.

e-policy cycle (left) and policy cycle (right)
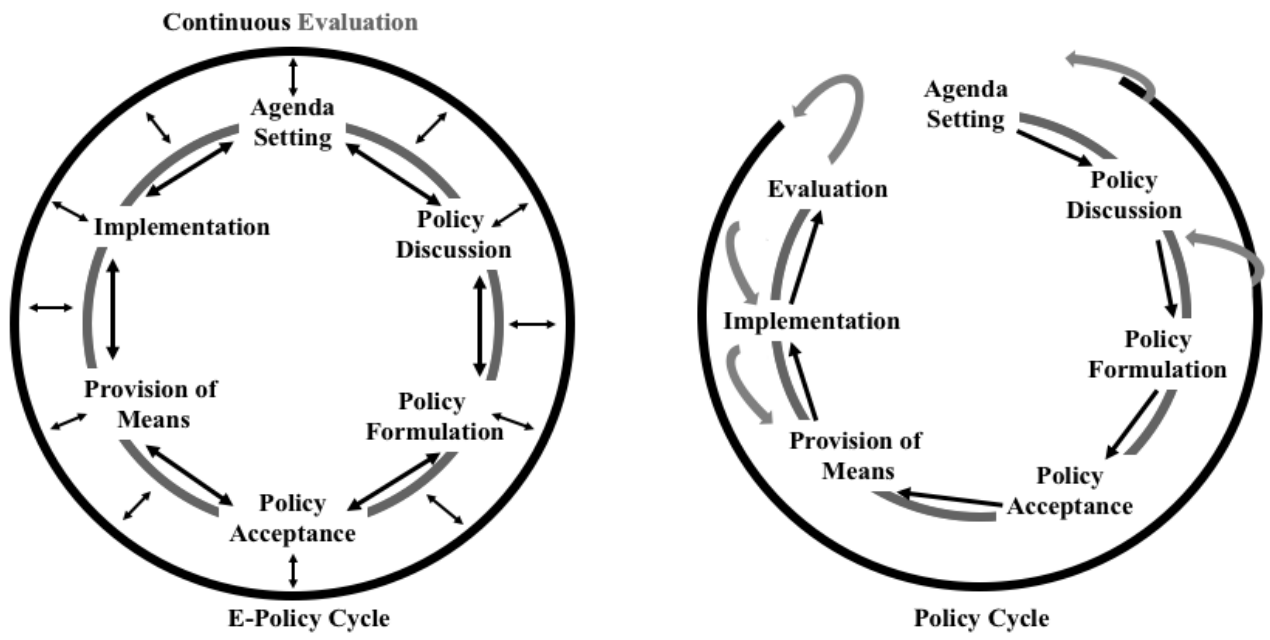

Source: Höchtl et al. (2016) 
Considering the environmental development and technical extraction of information from large amounts of data (big data) or Big Data Analytic (BDA), Höchtl et al. (2016) see the possibility of policy evaluation to be carried out continuously. According to Donnell (2001), the internet can accommodate issues that are not published by mainstream media. In other words, the internet can also be an alternative data source to see the community's response to policies that are being implemented. The use of data from the internet and BDA is shown by countries such as China or Singapore which instead of prohibiting political discussion, they actually observe and quantify it to get information about their community policy preferences and use them as early warning systems for potential political unrest (King, Pan, \& Roberts, 2013).

\section{Conceptualization of Cultural Public Sphere}

In general, there are two concepts of public sphere, namely political public sphere and literary public sphere (Habermas, 1991). The news from the mass media that is usually read every day is categorized as a political public sphere. The public sphere is bound to journalistic regulations that must be fulfilled. Conversely, literary public sphere, which was later expanded by McGuigan (2005) as a cultural public sphere concept, tends to be more flexible. Cultural public spheres are public space that refer to political, public and individual articulations through affective communication (aesthetic and emotional) models. Therefore, the cultural public sphere can provide an arena of deep reflection from the people involved in it (McGuigan, 2005).

The cultural public sphere in the context of the existence of the internet and specifically social media, functions to increase public awareness of social issues on one hand, and policy makers on the other hand. In other words, social media functions to disseminate information, or in Lim's terms (2017a) is called to compile hidden transcripts. Scott (1990) defines hidden transcripts as a subaltern party's constant struggle zone against domination, where the transcript also serves to maintain hope (Squires, 2002). That is, as a media to spread the message, as said by Dahlberg (2014) the public sphere must be inclusive, so that it allows everyone to be involved in it.

Therefore, the three dimensions of public sphere introduced by Dahlgren (2005) can be used to identify the existence of public sphere on social media. These three dimensions are structural dimensions, representations, and interactions. Here, it explores each one of the three dimensions of the problem, namely the dynamics of inclusivity, pluralism of views, and interaction between citizens, and between citizens and the media.

The structural dimensions of public sphere refer to the ways of organizing certain communicative spaces, namely, problems of access, freedom of speech and the dynamics of inclusivity/exclusivity (Dahlgren, 2005). In line with this, Schneider (1996) refers to it as "conversational arena" or "forum." Referring to discussions on the internet or often called computer-mediated, discussions can occur in two ways, namely moderated and not moderated. In moderation, there is one person or one group that moves and directs the discussion, usually by giving a theme. This can be found at the beginning of the development of discussions on the internet such as newsgroups (Schneider, 1996). Not being moderated means that an issue is discussed because there are many people who feel it is important to discuss. In the context of social media, inclusive means there is a common opportunity for each participant to question any hesitation and to express attitudes, desires and needs (Dahlberg, 2014).

The representational dimension of public sphere refers to the results of the inclusiveness of public sphere. Things included in this dimension are views of pluralism, ideology, and 
discussed issues (Dahlgren, 2005). According to El-Nawawy et al. (2010) Social media users tend to interact with users who also become friends in real life, so that even in cyberspace they might be able to form virtual communities and create collective identities. Witteborn (2007) defines collective identity as harmony between people who express and make themselves as group members. The harmony means certain modes of action and lifestyle, orientation, and expectations about what it means to be someone and group members' (Witteborn, 2007). One example of this identity can be found in the case of the revolution in Tunisia where the dissemination and framing of the narrative took place in social media (Lim, 2013b). For that case, the dimensions of interaction on social media can be analyzed using Social Network Analysis (SNA) to find different communities as indicated by previous studies (see: Batorski \& Grzywińska, 2017; Dumas et al., 2015).

Interactional dimensions refer to the results of interactions between citizens and citizens and between citizens and the media content used (Dahlgren, 2005). In other words, the interactional dimension produces what is called public opinion, public intellectual, or in more specific contexts, it can be referred to as shared common concerns (Lim, 2013b). In this context, the common concern is the result of development. For this reason, in addition to reviewing the narrative of the framing the condition according to citizens, this dimension is also evaluated by looking at the actions related to the emerging discourse. Thus, hashtag has the potential to bring up cultural public sphere in one of its three faces, namely critical intervention in the form of popular culture (McGuigan, 2005). Borrowing a term from Dahlgern (2005), it is considered as one of the emergence of indications of a new way of indirectly participating in managing the government.

Therefore, the researcher considers social media to be one of the places where affective narratives can grow to form a cultural public sphere. It uses that policy makers can use it as a source of data in determining the agenda and evaluating policies. For this reason, the main question of this research is: how do citizens construct narratives that shape cultural public sphere through tweeting with the \#JogjaOraDidol hashtag?. It is divided into three sub questions about three dimensions of public sphere, they are:

- Structural dimensions: What are the citizen's activities in using the \#JogjaOraDidol hashtag on Twitter?

- Representational dimension: How are virtual communities formed in the network of \#JogjaOraDidol hashtag users? How does the community represent themselves?

- Interactional dimensions: What is the representation of citizens' responses to the policies for the construction of hotels, malls, apartments and spatial structures constructed on social media?; what are the preferences of citizens related to the policy?; what is the real form of the developing discourse?

\section{Methods}

The data used in research are taken from Twitter by using the screen scrapping method. It is a common method for getting online data that can be viewed on a computer screen. The keyword used is the \#jogjaoradidol hashtag in the period from October 72017 to October 31, 2017 (16,453 tweets). In addition, other data used in this study are online media obtained by the same method using the keywords of hotel development and Jogja Ora Didol. Lastly, to complete the data triangulation process, researcher collected data from key informants.

The three data sources are used because this study uses a mixed method between Topic Modelling, Social Network Analysis, and Discourse Analysis. Therefore, this study can be categorized as a Corpus Assisted Discourse Studies that is a study that utilizes algorithms 
and computer science to extract discourse from data in the form of text (Partington, Duguid, and Taylor 2013, 10). In this context, some previous studies suggested using mixed methods to uncover the truth in developing discourse (See: Dahlberg 2014; Etling, Roberts, and Faris 2014).

Discourse analysis begins with extracting topics from tweets automatically. Here, the researchers applied the algorithm developed by Blei et al. (2003), namely Latent Dirichelet Allocation (LDA) in text that has gone through pre-processing stages such as stopwords removal, word normalization, and eliminating URLs. The text that has been cleaned later becomes one, or bags of words without removing the identity (id) of the document (tweet) so that the researcher gets 179,134 terms.

Furthermore, the topics obtained are classified to form separate themes related to the developing movement. Classification is based on the same reference data from two other data sources, namely media and interview results. In other words, discourse analysis is referred to as intertextuality, that is a method of finding the context of a text based on other texts (Gee 2011, $54)$. In the same concept, Quinn et al. $(2010,216)$ refer to it as intra-semantic-validity, where in this study, each topic obtained was examined qualitatively.

\section{Discussion}

\section{Structural Dimension: Hashtag as an inclusive space}

To answer the first question, tweet distribution anomalies were detected using Twitter anomaly detection. In addition, to find out the dynamics of inclusiveness in the use of hashtags, researcher also examined changes in the main actors in each period. The last study was carried out on various actions related to movements that occurred and were carried out by movement supporters.

In general, tweet distribution anomalies only occur in the first two years where hashtags are still in the initial stages of occurrence (Figure 2). In general, the number of Twitter users who use hashtags decreases in quantity, but in each period, there are different account names that become the account/main actors driving virtual use of tags and movements (Figure 3).

Based on the search, the accounts with the highest frequency in each period are owned by

\section{Figure 2.}

Twit Distribution Anomaly with\#JogjaOraDidol Hashtag

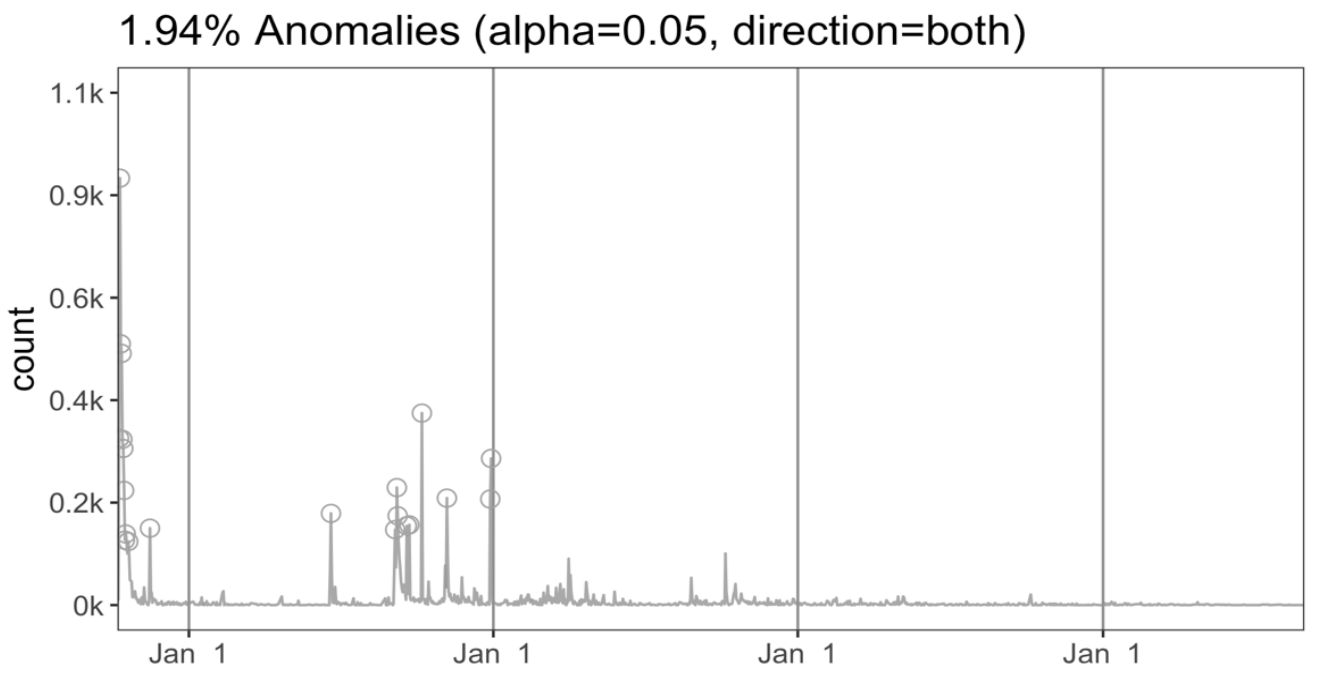

Source: processed from data distribution of tweets containing \#jogjaoradidol hashtag 
Figure 3.

Account names that are most often involved in tweets with the \#JogjaOraDidol Hashtag



Source: processed from data distribution of tweets containing \#jogjaoradidol hashtag

artists or musicians, social movement activists, or community accounts. For example, in the first period, the @JogjaOradidol account was a twitter account created to socialize the "Jogja Not for Sale" movement campaign. Meanwhile, the most frequently involved account in the following period was the @rembugjogja account, an account which was made to discuss various things about Yogyakarta, such as the description of their profile as follows.

"Better public discussion sphere for Jogja. Criticism \& Suggestion is a reflection of our expressions of love and concern for Jogja. rembugjogja@ gmail.com."

In the third period, the most involved account was the activist of the empowered citizen movement (@wargaberdaya),namely@ dodoputrabangsa who was also an actor in an act of protest in the form of art. Meanwhile, in the last period an account, it appeared under the name @joeyakarta who was also an activist for social and environmental movements.

Furthermore, to find out the background context of using hashtags, the anomalies that occur, and the emergence of the accounts above, researcher conducted intertextuality through other data sources (interviews, and mass media publications) to find out events related to hashtags that occurred in the City Yogyakarta. The results can be seen in Table 1 .

Table 1 above shows that in the tweet period in the data, there were several actions in the real world that were used as media to protest development policies. Even though the researcher is not testing the correlation between the number of actions and the number of Twits, it can be identified that the number of twins that tend to be more in the early period (2013-2014) coincides with the three major actions that followed and received quite a lot of public attention. For example, a music concert, the event was very likely to be attended by thousands of people. Meanwhile, 
Table 1.

Action on rejection of development in the city of Yogyakarta

\begin{tabular}{clll}
\hline No & \multicolumn{1}{c}{ Date } & \multicolumn{1}{c}{ Name of the Actions } & \multicolumn{1}{c}{ Place } \\
\hline 1 & 13 September 2013 & $\begin{array}{l}\text { Happening art with the title “Postcards for } \\
\text { Cities: Bad News for Haryadi" }\end{array}$ & KM 0, Yogyakarta \\
2 & October 2013 - March 2014 & $\begin{array}{l}\text { Art/mural festival with the title "The Search for } \\
\text { Haryadi Festival" }\end{array}$ & The city of Yogyakarta \\
3 & 06 August 2014 & Bath in ash theatrical action & In front of Fave Hotel \\
4 & 06 September 2014 & Music Concert & North Square \\
5 & 14 January 2015 & Film screenings with the title "Behind the Hotel" & PKKH, UGM \\
6 & 08 April 2015 & Moment of silence & North Square of Yogyakarta \\
7 & 14 February 2016 & Campaign "Ayo Gawe Kebon, Ojo Nandur & Roundabout of UGM \\
& & Beton/Make a garden, Don't Plant Concrete" & \\
\hline
\end{tabular}

Source: processed from various online media sources and participant information

the happening art, and art festival are known to be one of the main events that underlie the existence and use of \#JogjaOraDidol hashtags. Theatrical action, on the other hand, the actors who did it later received attention from mainstream mass media and became one of the speakers in the talk show on national TV.

The facts mentioned above indicate that hashtags are the place where public discussions about a social issue begin. In this context, issues are related to property development and spatial planning in the city of Yogyakarta. In the end the mainstream media also gave attention and raised it as a news or show. This is in line with the findings of Bonilla et al., (2015) who stated that social media is very likely to be used to discuss issues that didn't the attention of mainstream media.

The results of research show that in each period, there are different actors indicate the dynamics that are open for everyone to be the center of the developing discourse. The emergence of these actors is at least influenced by two things, namely: first, the number of tweets they send; second, their reputation. Reputation can be a default reputation, for example, the owner of the account is already famous in the real world. Reputation can also be built on the content they share in accordance with the meanings, feelings and/or anxieties felt by other users. Therefore, in line with
Papacharissi (2009) and Batorski et al. (2017), the dynamics of inclusivity or exclusivity are not always related to web 2.0 specifications, but also related to the political articulation of social media users. In the context of "Jogja Not For Sale" the dynamics of inclusivity/exclusivity also relates to the existence of events that trigger and actors of the event.

\section{Representational Dimension: Hashtag As Collective Identity}

The second question in this study relates to the existence of a virtual community and representation of the community in supporting the "Jogja Not for Sale" movement. To answer the question, it first used SNA, and then divided the tweet based on the sender's account per modularity class. Furthermore, the existence of a virtual community in the \#JogjaOraDidol hashtag user network can be seen in Figure 4.

Figure 4 shows that hashtag users are divided into several modularity class groups. First class/group $=$ modularity class 0 consists of 38 Twitter accounts; class/second group consists of 13. Class/group 3 consists of 48 accounts, class/group 4 consists of 56 accounts, and class/group 5 consists of 60 accounts. Classes 6,7 and 8 each consist of 1,2 , and 42 accounts. Considering the amount of content that will then be used to confirm the representation and existence of the community in the real world, 
Figure 4.

Networking of the hashtag \#jogjaoradidol user

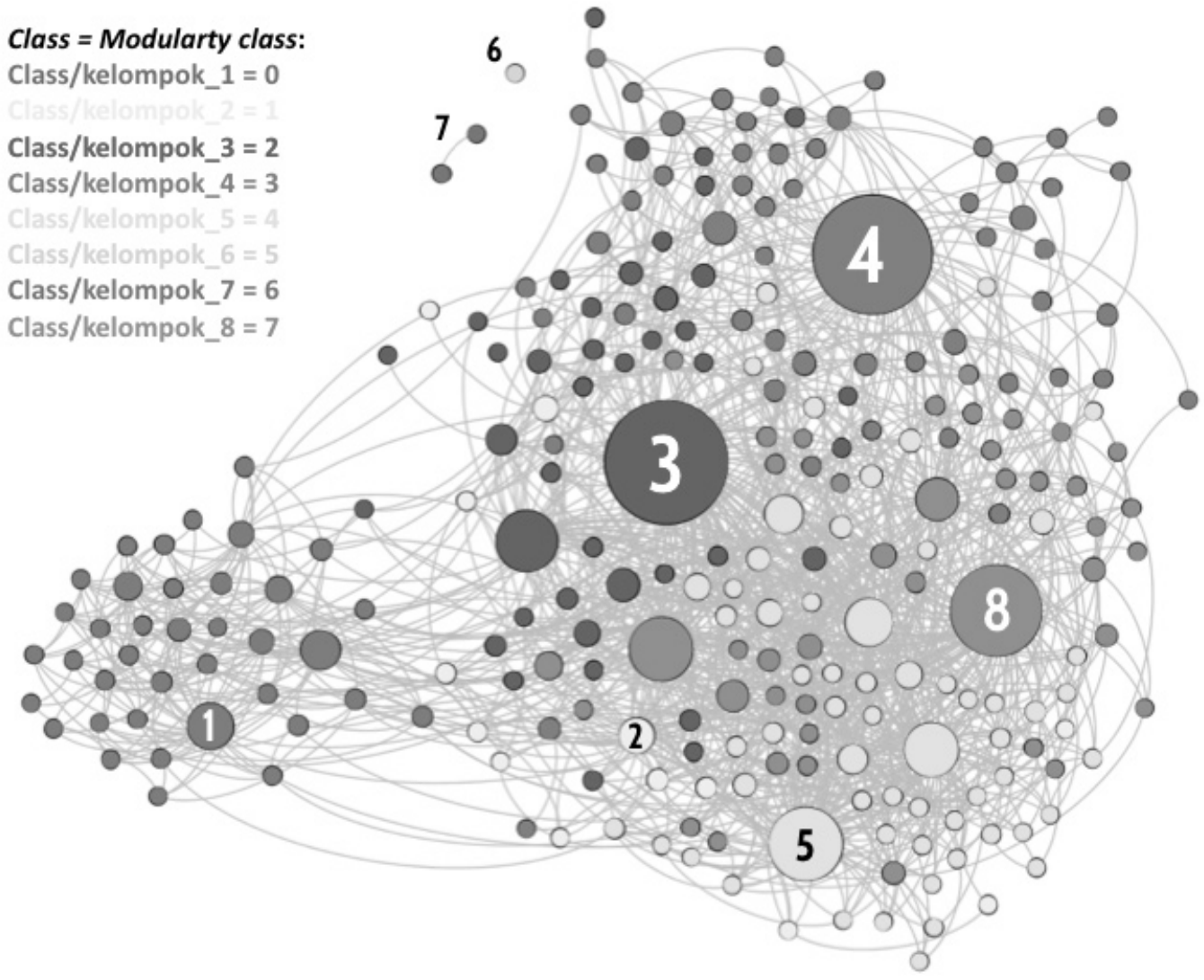

Source: Processed from username of tweets containing \#jogjaoradidol hashtag

Description: colors are based on modularity class, large nodes are based on betweenness centrality. Network only displays nodes with a minimum of 10 degrees $(4.83 \%$ nodes and $12.88 \%$ edges), where is nodes = username, while edges = co-occurrence.

classes/groups 2, 6, and 7 are then considered unanalyzed because the content is too small.

To find out the representation of each group, the researcher then analyzed the content and used the eigencentrality to get the Tweet to be read qualitatively. Figure 5 below shows the accounts that become influencers in each remaining group, namely classes/groups 1, 3, 4,5 , and 8 .

Based on analysis of content and qualitative analysis here, it is found three large groups of \#JogjaOraDidol hashtag users on Twitter. First is the fan community, that is a group that contains fan accounts of the JKT48 vocal group. Here, they call themselves @JKT48JOGJAFC and are in class/group 1.
Second is the community of artists consisting of musicians and painters both from Yogyakarta and outside other regions in Indonesia. Here, this community is represented by class/group 3 and 8 , where in the group the most influential accounts are musicians. For example, @killthedj is a rapper belonging to the Jogja Hip Hop Foundation music group, while @JRX SID is a Superman Is Dead drummer from Bali. Third is activist community (class/group 4 and 5). The last group is called activist groups because the most influential accounts for the group were identified as belonging to social and environmental movement activists. In addition, this group also had a different representation in supporting the "Jogja Not for Sale" movement 
Figure 5.

Influencers of each group

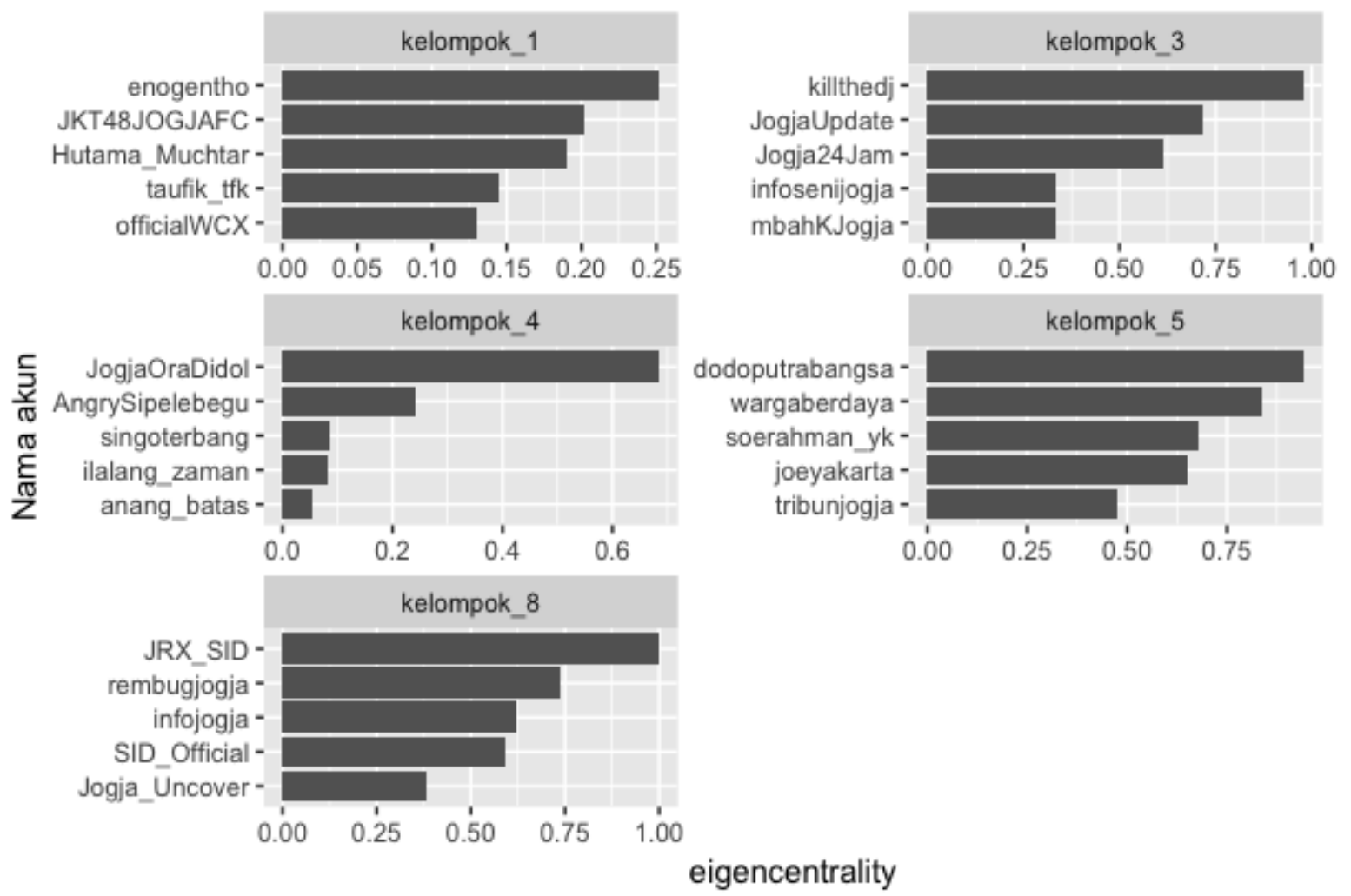

Source: processed from data distribution of tweets containing \#jogjaoradidol hashtag

campaign compared to the two previous groups.

JKT48 Fans Community supports and participates in promoting the "Jogja Not for Sale" movement by making a parody video with the title "Kokoro Placara No/Heart Fill Marker Board." The signboards are used as symbols about the condition of the city according to them and their expectation. Slightly similar to the fan community, musicians who are members of the artist community also create songs to support and campaign for the movement. Among the songs that are mostly talked about are songs with the titles "Jogja Ora Didol" made by JHF and "New Yorkarta" created by the "Under Fire Heat" Band. Besides the songs, representations from this community can also be found in the form of music concerts that are conducted as one of the events to campaign for the movement.

The existence of the three communities mentioned above, on one hand is in line with the wrong criteria of representational dimensions of public sphere proposed by Dahlgren (2005). It is the existence of pluralism of view. In this context, pluralism can be seen both from the differences of the community and from its representation in supporting and campaigning for the movement. On the other hand, the results of the study also show that each modularity class has the same message about the condition of the city of Yogyakarta, which for them is no longer comfortable, as shown in the following twit.

“\{@User]: \{@User] \{@User] in general the Yogyakarta jargon of Being Comfortable is irrelevant, Yogyakarta has stopped being comfortable \#jogjaoradidol"

This shows that citizens have what is called by Lim (2013b) as a shared common concern, where through the hashtag, citizens 
share experiences with the same meaning about changes that occur in the city of Yogyakarta. In line with Witteborn (Witteborn, 2007), hashtag is a collective identity about the feeling of "partial" citizens of the City of Yogyakarta represented by three groups found here. In addition, the formation of a collective identity also indicates the existence of a user's understanding and awareness of the possibility of the presence of others in the space used. In this context the \#JogjaOraDidol hashtag user shows what Dahlberg (2014) calls as "ideal role taking" which is also one of the characteristics of public sphere.

\section{Interactional Dimensions: Hashtag as a Policy Map}

Topic modeling using the Latent Dirichlet Allocation (LDA) algorithm introduced by Blei (2003) was used to answer the third question, namely interactional dimensions. Figure 6 below shows the results of the analysis carried out.

The distribution of topics discussed by Twitter users with the hashtag \#JogjaOraDidol has the same pattern, namely the majority tends to come from documents (tweets) sent at the end of 2013, and early 2015 as can be seen in the picture above. To validate it, the researcher then conducted an independent investigation of the top terms of each topic or Quinn et al. (2010) call it the intra-topic semantic validity. Technically, the researcher sampled documents from each topic, read them manually, and summarized them as suggested by Maier (2018) in the use of Topic Modeling. Subsequent investigations produce topic labels as can be seen in the table 2 .

The first topic category is general and remains central all the time. The main narrative is related to events that triggered the use of hashtags on social media. It includes the arrest of Muhammad Arif, support videos for campaign movements made by fan groups, and Yogyakarta City birthdays that took place

Figure 6.

Development of topics discussed on Twitter
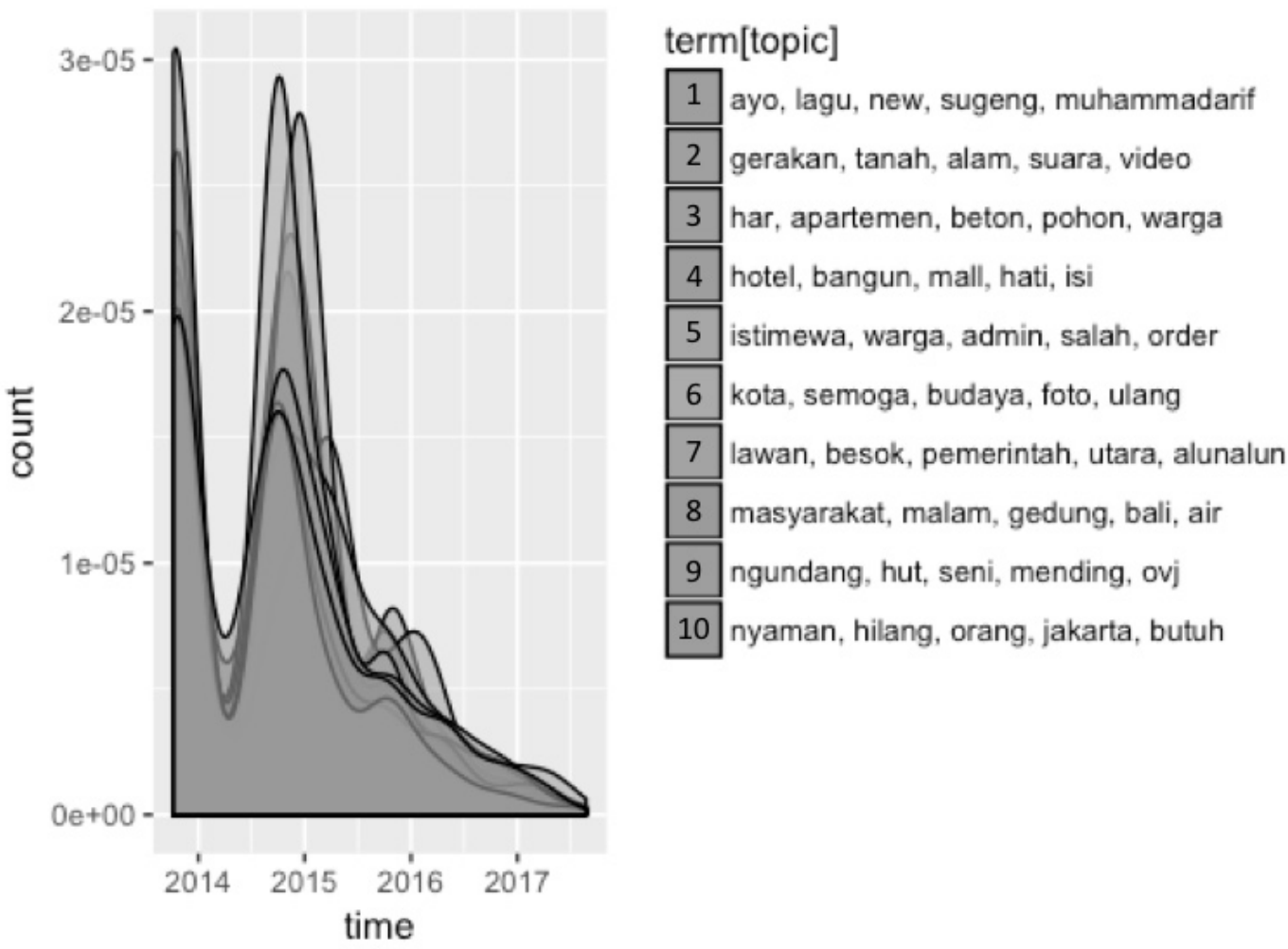

Source: processed from data distribution of tweets containing \#jogjaoradidol hashtag 
Table 2.

\section{Categorization of topics from Topic} Modeling

\begin{tabular}{|c|c|c|}
\hline Category & Term topic & Context \\
\hline $\begin{array}{l}\text { Awareness } \\
\text { about the } \\
\text { condition of } \\
\text { the city }\end{array}$ & $\begin{array}{l}\text { come on, song, } \\
\text { new, sugeng, } \\
\text { muhammadarif } \\
\text { movement, land, } \\
\text { nature, sound, video } \\
\text { city, hopefully, culture, } \\
\text { photos, birthday } \\
\text { invite, hut, art, better, } \\
\text { ovj }\end{array}$ & $\begin{array}{l}\text { The beginning } \\
\text { of the } \\
\text { emergence of } \\
\text { movements } \\
\text { and hashtags } \\
\text { on social media }\end{array}$ \\
\hline $\begin{array}{l}\text { Citizens' } \\
\text { anxiety }\end{array}$ & $\begin{array}{l}\text { har, apartments, } \\
\text { concrete, trees, } \\
\text { residents } \\
\text { hotel, wake up, mall, } \\
\text { heart, fill } \\
\text { comfortable, lost, } \\
\text { person, jakarta, need }\end{array}$ & $\begin{array}{l}\text { Development } \\
\text { that has a } \\
\text { negative } \\
\text { impact }\end{array}$ \\
\hline $\begin{array}{l}\text { Actor } \\
\text { construction }\end{array}$ & $\begin{array}{l}\text { opponent, tomorrow, } \\
\text { government, north, } \\
\text { square } \\
\text { community, night, } \\
\text { building, Bali, water } \\
\text { special, citizen, admin, } \\
\text { wrong, order }\end{array}$ & $\begin{array}{l}\text { City } \\
\text { government, } \\
\text { provincial } \\
\text { government } \\
\text { and residents } \\
\text { of Yogyakarta } \\
\text { City }\end{array}$ \\
\hline
\end{tabular}

Source: Classification of results of primary data modeling topics (tweets)

in October. In this context, the anniversary discussed was the $257^{\text {th }}$ anniversary of the city in 2013. In addition, in the topic in the first category, there was also a narrative about the form of community responses to the city changes they felt, namely art and cultural activities as can be seen on the following tweet.

"[@User]: the cultural line" Merapi palace "on the Mangkubumi road has turned into a commercial line with hotels in this area \#jogjaoradidol"

The second topic category is more specific to discuss the things underlying the emergence of some of \#JogjaOraDidol's movements, actions, and hashtags. They include the construction of hotels, malls, and apartments. In addition, on the topic of this second category, it is found such Tweet, which pretty much discusses the mayor of Yogyakarta City, namely Haryadi Suyuti. She is symbolized by the emergence of the term "har." Other symbols are also widely used to represent anxiety due to the impact of development of "concrete forests" and "Jakarta" as shown in the following tweet.

"[@User]: Jogja tastes Jakarta when the JOG is gone from JOGJakarta \#JogjaOraDidol."

Finally, the third topic category contained narratives which partly came from the tweet posted at the end of 2014 and early 2015. The narrative was dominated by discourse about the mayor of the city of Yogyakarta, the provincial government, and the citizens. The discourse about the mayor is based on citizen dissatisfaction with the performance of the Mayor who is considered to be in the interest of the public interest. Meanwhile the narrative about the provincial government which in this case symbolized by the "Sultan" was motivated by the statement of the Governor of Yogyakarta Special Region (DIY). It had been done after watching a documentary titled "Behind the Hotel / Back of Hotels." After watching the film, the "Sultan" was shocked by the number hotel built in the city of Yogyakarta and its impact on the community. In addition, the Sultan also gave awards to a movement supporter. This did not escape the attention of citizens such as tweets from one of the following accounts who also got lots of retweets from other users. “[@User]: Sri Sultan Hamengku Buwono $X$ handed the \#WALHI award to one of the supporters \#JogjaOraDidol [@User]"

In addition to the narrative about the two government actors above, in this category, there is also a concept of developing citizens. First are residents who are aware of the hashtag. Second are residents of internet users and especially Twitter were targeted by the campaign "Jogja Not for Sale." In other words, the use of \#JogjaOraDidol hashtag was not much different from previous studies on the function of social media in real life, 
namely to disseminate information. However, the hashtag is also used by the community to show what they want in the city of Yogyakarta. It assesses the policies that are being implemented as stated in the two tweets below.

@User]: rather than building a mall, and hotels, it is better to built city parks har \#JogjaOraDidol; @User]: the moratorium on apartment construction permission actually accelerates development, but the development moratorium is more suitable for \#SlemanAmbyar \#JogjaOraDidol \#JogjaKangenKPK.

The Yogyakarta City Government responded to the problem of hotel construction by issuing a moratorium policy on granting building permits. This policy was officially implemented in January 2014, and was valid until December 2016. Based on the emerging narrative, residents initially requested the policy. Nevertheless, because the policy is only valid for two years, the public asks the impact of policies that can be felt. After that, the city government of Yogyakarta extended the period of the moratorium policy until December 2018. However, residents considered that the moratorium policy actually accelerated the construction of the hotel. As noted by the Powerful Citizens community: the number of star hotels in the city of Yogyakarta in 2014 was around 40, while in the following year (2015) there were 20 new hotels built. In 2016, there were 254 hotels in Yogyakarta city or more than half of hotels in DIY. That is, after the adoption of the hotel moratorium policy for hotel development increased by almost 50 percent every year. The number will increase if combined with the number of non-star hotels, where in 2016 in the city of Yogyakarta there are already around 2118 non-star hotels (BPS, 2008, 2013, 2014, 2015, 2016).

As explained by Dahlgren (2005), the interactional dimension consists of two communication patterns, namely between actors, and between actors and the media used. In this context, the results of the modeling topic show that the topics that develop on social media cannot be separated from the background context, namely various events and protests carried out in the real world. In this context, social media functions to spread the messages of these various actions and the hashtags are used to get immediate attention. This is indirectly in line with one way of making hidden transcripts delivered by Scott (Scott, 1990), namely the use of slogans in movements and as said by Lim (2013a), that, social media is one of the media to disseminate hidden transcripts.

The fact that Twitter users use more cultural values, especially those close to the community including slogans in Javanese, indicates that narratives on social media are built with simple language, symbols, and frames. It is in line with Lim (2013b) who said that social media is not suitable for disseminating complex content and severe problems, where in the context of the \#JogjaOraDiol hashtag, the issue conveyed by citizens via Twitter tends to originate from the daily experience of social media users. They are all such as wells that lost water, congestion, Mount Merapi which is not seen and the like.

The issues conveyed by citizens through social media may actually be more complex, but it can be seen that these issues tend to be simplified. For example, dry wells are caused by the presence of hotels that also use ground water. On one hand, empirical truths about the causes of dry wells still need to be proven. But on the other hand, it is in line with Squires (2002) who says that the narrative of hidden transcripts is not only used to fight domination, but also serves to maintain the expectations of its makers. In this context, narratives on social media are used to bring hope to the condition of the city that the citizen wants. So that the emergence of the construction of three actors, namely the Mayor, Governor, and Society can be understood as one of the strategies 
to realize this desire.

Therefore, the interaction between social media users, and between users and the media (interactional dimension) is considered to produce "social constructed constructed". It is a collective awareness and knowledge formed by the interaction between actors and the meanings of each actor (Berger \& Luckmann, 1966). Thus, in the context of using the \#JogjaOraDidol hashtag on Twitter the researcher agrees with Koltsova et al. (2013) and Ceron et al. (Ceron \& Negri, 2016) who said that social media (blogs and microblogs) can be utilized in the policy making process, especially in the Agenda Setting stage. In this stage, policy makers need to know and have evidence about things that concern the community. In addition, data on public opinion on social media, in the context of the city of Yogyakarta can also be used to see how public acceptance of a policy, in this context, the moratorium policy on building permits. In other words, in line with the assumption of Höchtl (2016) the development of information technology and BDA allows policy evaluation to be carried out continuously.

\section{Conclusions}

Using a mixed method between Topic Modeling, SNA, and Discourse Analysis, this article contributes to academic and professional debates on how community roles and participation in social media should be seen and utilized in the e-policy cycle (Höchtl et al., 2016). By focusing on affective narratives that shape cultural public sphere as conceptualized by McGuigan (McGuigan, 2005) and by using the characteristics of three dimensions of public sphere introduced by Dahlgren (2005), it can be concluded that in the context of the existence of \#jogjaoradidol hashtags, there are three dimensions of public sphere.

The existence of these three-dimensional characteristics is indicated by the existence of an open (inclusive) sphere, the existence of different communities, and simple narratives made. They are all to reflect the desires of some urban communities in relation to their environmental conditions. Therefore, the public formed sphere is a cultural public sphere, namely a political articulation through an affective communication model. In this context, the \#JogjaOraDidol hashtag was used as a marker of the response of some people who had the same experience and knowledge about the changes that took place in the city of Yogyakarta and its effects. The response is represented by cultural actions in the real world and simple narratives that invite sympathy in cyberspace.

Therefore, the narrative that develops in cyberspace can be a source of data for policy makers to set agendas and conduct policy evaluations. Through simple narratives in cyberspace, citizens show things such as in case of what make them restless, things they want, and who must fulfill those desires. In other words, policy makers can see issues of mutual concern in the city of Yogyakarta, which are related to the impact of the construction of hotels, apartments, and malls that are considered detrimental to the community. In addition, policy makers can also see the public response to the policies implemented, namely the moratorium on granting development permits, which are actually considered to accelerate hotel growth by citizens.

\section{References}

Barlow, A. (2008). Blogging America: The New Public Sphere. (R. Anderson, Ed.) (1st ed.). Westport: Praeger Publishers.

Batorski, D., \& Grzywińska, I. (2017). Three dimensions of the public sphere on Facebook. Information, Communication \& Society, 1-19. doi: 10.1080/1369118X.2017.1281329

Beers, D. (2006). The Public Sphere and Online, Independent Journalism. Canadian Journal of Education, 29(1), 109-130.

Berger, P. L., \& Luckmann, T. (1966). The social 
construction of reality. London: Penguin Group. doi: 10.2307/323448

Blei, D. M., Y.Ng, A., \& Jordan, M. I. (2003). Latent Dirichlet Allocation. Journal of Machine Learning Research, 3, 993-1022.

Bonilla, Y., \& Rosa, J. (2015). \#Ferguson: Digital protest, hashtag ethnography, and the racial politics of social media in the United States. American Ethnologist, 42(1), 4-17. doi: 10.1111/amet.12112

BPS Provinsi Daerah Istimewa Yogyakarta. (2016). Direktori Hotel dan Akomodasi Lain Daerah Istimewa Yogyakarta. Yogyakarta: BPS Provinsi Daerah Istimewa Yogyakarta.

Brenne, S. (2016). Political Discussion on Social Media and the Public Sphere. Sociology and Anthropology, 4(4), 270-275. doi: 10.13189/ sa.2016.040410

Calhoun, C. (2014). Civil society and the public sphere. In M. Edwards (Ed.), The Oxford Handbook of Civil Society (pp. 311-323). New York. doi: 10.1093/ oxfordhb/9780195398571.013.0025

Castells, M. (2008). The New Public Sphere: Global Civil Society, Communication Networks, and Global Governance. The Annals of the American Academy of Political and Social Science, 616, 78-93. doi: 10.1177/0002716207311877

Ceron, A. (2017). Social Media, Collective Action and Public Policy. In Social Media and Political Accountability (pp. 133-156). Cham: Springer International Publishing. doi: 10.1007/978-3-319-52627-0_7

Ceron, A., \& Negri, F. (2015). Public policy and social media: How sentiment analysis can support policy-makers across the policy cycle. Rivista Italiana Di Politiche Pubbliche, 10(3), 309-338. doi: 10.1483/81600

Ceron, A., \& Negri, F. (2016). The "Social Side" of Public Policy: Monitoring Online Public Opinion and Its Mobilization During the Policy Cycle. Policy and Internet, 8(2), 131-147. doi: 10.1002/poi3.117

Chen, P. J. (2013). Policy in an age of information.
In Australian Politics in a Digital Age (p. 286). Canberra: ANU E Press.

Curran, J. (1993). Rethinking the media as a public sphere. In P. Dahlgren \& C. Sparks (Eds.), Communication adn Citizenship: Journalism and the public sphere (3rd ed., pp. 27-56). London and New York: Routledge.

Dahlberg, L. (1998). Cyberspace and the public sphere: Exploring the democratic potential of the Net. Convergence, 4(1), 70-84.

Dahlberg, L. (2007). The Internet and Discursive Exclusion: From Deliberative to Agonistic Public Sphere Theory. In L. Dahlberg \& E. Siapera (Eds.), Radical Democracy and the Internet: Interrogating Theory and Practice (p. 262). New York: Palgrave.

Dahlberg, L. (2014). Net-Public Sphere Research: Beyond The "First Phase." Javnost - The Public, 11(1), 27-43. doi: 10.1080/13183222.2004.11008845

Dahlgren, P. (2005). The internet, public spheres, and political communication: Dispersion and deliberation. Political Communication, 22(2), 147-162. doi: 10.1080/10584600590933160

Dahlgren, P. (2013). The political web: Media, participation and alternative democracy. Basingstoke: Palgrave Macmillan.

Dhillon, A. (2014). Social Media and Revolution: The Importance of the Internet in Tunisia's Uprising (Independent Study Project (ISP) Collection No. 1938).

Donnell, S. O. (2001). Analysing the internet and the public sphere: The case of womenslink. Javnost - The Public, 8(1), 39-58. doi: 10.1080/13183222.2001.11008764

Dumas, C. L., LaManna, D., Harrison, T. M., Ravi, S., Kotfila, C., Gervais, N., ... Chen, F. (2015). Examining political mobilization of online communities through e-petitioning behavior in We the People. Big Data E Society, 2(2), 205395171559817. doi: 10.1177/2053951715598170

El-Nawawy, M., \& Khamis, S. (2010). Collective identity in the virtual islamic public sphere: 
Contemporary discourses in two Islamic websites. International Communication Gazette, 72(3), 229-250. doi: 10.1177/1748048509356949

Eltantawy, N., \& Wiest, J. B. (2011). Social media in the Egyptian revolution: Reconsidering resource mobilization theory. International Journal of Communication, 5, 1207-1224. doi: 1932-8036/2011FEA1207

Etling, B., Roberts, H., \& Faris, R. (2014). Blogs as an Alternative Public Sphere: The Role of Blogs, Mainstream Media, and TV in Russia's Media Ecology. The Berkman Center for Internet $\mathcal{E}$ Society Research Publication Series (Vol. 8). doi: 10.2139/ssrn.2427932

Habermas, J. (1991). The structural transformatin of the public sphere: An inquery into a category of burgeois society. Massachusetts: MIT Press. doi: 10.1017/CBO9781107415324.004

Heijden, H.-A. van der. (2010). Social movements, public spheres and the european politics of the environment: Green power Europe? Hampshire: Palgrave and Macmillan.

Höchtl, J., Parycek, P., \& Schöllhammer, R. (2016). Big data in the policy cycle: Policy decision making in the digital era. Journal of Organizational Computing and Electronic Commerce, 26(1-2), 147-169. doi: 10.1080/10919392.2015.1125187

King, G., Pan, J., \& Roberts, M. E. (2013). How censorship in China allows government criticism but silences collective expression. American Political Science Review, 107(2), 326-343. doi: 10.1017/S0003055413000014

Koltsova, O., \& Koltcov, S. (2013). Mapping the public agenda with topic modeling: The case of the Russian live journal. Policy and Internet, 5(2), 207-227. doi: 10.1002/19442866.POI331

Kusumasari, B. (2014). Social media dan eksklusi remaja dalam perumusan kebijakan publik. Jurnal Kebijakan \& Administrasi Publik, 18(2), 119-129.

Levasseur, D. G., \& Carlin, D. B. (2001). Egocentric argument and the public sphere: Citizen deliberations on public policy and policymakers. Rhetoric and Public Affairs, 4(3), 407-431.

Lim, M. (2012). Clicks, cabs, and coffee houses: Social media and oppositional movements in Egypt, 2004-2011. Journal of Communication, 62(2), 231-248. doi: 10.1111/j.1460-2466.2012.01628.x

Lim, M. (2013a). Digital media and malaysia' s electoral reform movement. In $W$. Berenschot, H. S. Nordholt, \& L. Bakker (Eds.), Citizenship and Democratization in Southeast Asia (pp. 224-251). Leiden: Brill Academic Publisher.

Lim, M. (2013b). Framing Bouazizi: “White lies", hybrid network, and collective/ connective action in the 2010-11 Tunisian uprising. Journalism, 14(7), 921-941. doi: $10.1177 / 1464884913478359$

Lim, M. (2013c). Many clicks but little sticks: Social media activism in Indonesia. Journal of Contemporary Asia, 43(4), 636-657. doi: 10.1080/00472336.2013.769386

Lim, M. (2017a). Digital Media and Malaysia's Electoral Reform Movement. In Ward Berenschot, Henk Schulte Nordholt, \& Laurens Bakker (Eds.), Citizenship and Democratization in Southeast Asia. Brill. doi: 10.1163/j.ctt1w76ws5.13

Lim, M. (2017b). Freedom to hate: social media, algorithmic enclaves, and the rise of tribal nationalism in Indonesia. Critical Asian Studies, 49(3), 411-427. doi: 10.1080/14672715.2017.1341188

Maier, D., Waldherr, A., Miltner, P., Wiedemann, G., Niekler, A., Keinert, A., ... Adam, S. (2018). Applying LDA topic modeling in communication research: Toward a valid and reliable methodology. Communication Methods and Measures, 00(00), 1-26. doi: 10.1080/19312458.2018.1430754

Marwick, A. E. (2014). Ethnographic and Qualitative Research on Twitter. In K. Weller, A. Bruns, J. Burgess, M. Mahart, \& C. Puschmann (Eds.), Twitter and Society (pp. 109-122). New York: Peter Lang. 
McGuigan, J. (2005). The cultural public sphere. European Journal of Cultural Studies, 8(4), 427-443. doi: 10.1177/1367549405057827

Mergel, I. (2017). Building Holistic Evidence for Social Media Impact. Public Administration Review, 77(4), 489-495. doi: 10.1111/ puar. 12780

Metzgar, E., \& Maruggi, A. (2009). Social Media and the 2008 U.S. Presidential Election. Journal of New Communication Reserach, 4(1), 141-166.

Mueller, P. S., \& van Huellen, S. (2012). A Revolution in 140 Characters? Reflecting on the Role of Social Networking Technologies in the 2009 Iranian Post-Election Protests. Policy \& Internet, 4(3-4), 184-205. doi: 10.1002/poi3.16

Oblak, T. (2002). Dialogue and representation: Communication in the electronic public sphere. Journal of the European Institute for Communication and Culture, 9(2), 7-22. doi: 10.1080/13183222.2002.11008797

Palen, L. (2008). Online Social Media in Crisis Events. Educause Quarterly, 31(3), 76-78.

Papacharissi, Z. (2002). The virtual sphere: The Internet asPublicSphere. New Media \& Society, 4(1), 9-27. doi: 10.1177/14614440222226244

Papacharissi, Z. (2009). The Virtual Sphere 2.0: The Internet, the Public Sphere and beyond. In A. Chadwick \& P. Howard (Eds.), Handbook of Internet Politics (pp. 1-35). Routledge. doi: 10.1111/1478-9302.12016_66

Quinn, K. M., Monroe, B. L., Colaresi, M., Crespin, M. H., \& Radev, D. R. (2010). How to analyze political attention with minimal assumptions and costs. American Journal of Political Science, 54(1), 209-228. doi: 10.1111/j.1540-5907.2009.00427.x

Sayre, B., Bode, L., Shah, D., Wilcox, D., \& Shah, C. (2010). Agenda Setting in a Digital Age: Tracking Attention to California Proposition 8 in Social Media, Online News and Conventional News. Policy $\mathcal{E}$ Internet, 2(2), 7-32. doi: 10.2202/1944-2866.1040

Schneider, S. M. (1996). Creating a democratic public sphere through political discussion: A Case study of abortion conversation on the internet. Social Science Computer Review, 14(4), 373-393.

Scott, J. C. (1990). Domination and the Arts of resistance: Hidden transcripts. London: Yale University Press.

Severo, M., Feredj, A., \& Romele, A. (2016). Soft data and public policy: Can social media offer alternatives to official statistics in urban policymaking?. Policy and Internet, 8(3), 354-372. doi: 10.1002/poi3.127

Sima, Y. (2011). Grassroots environmental activism and the internet: Constructing a green public sphere in China. Asian Studies Review, 35(4), 477-497. doi: 10.1080/10357823.2011.628007

Squires, C. R. (2002). Rethinking the black public sphere: An alternative vocabulary for multiple public spheres. Communication Theory, 12(4), 446-468. doi: 10.1111/j.14682885.2002.tb00278.x

Supeli, K. (2010). Ruang publik dunia maya. In F. Budi Hardiman (Ed.), Ruang Publik: Melacak "Patisipasi Demokratis" dari Polis Sampai Cyberspace (6th ed., pp. 329-346). Yogyakarta: Kanisius.

Theocharis, Y. (2013). The Wealth of (Occupation) Networks? Communication Patterns and Information Distribution in a Twitter Protest Network. Journal of Information Technology and Politics, 10(1), 35-56. doi: 10.1080/19331681.2012.701106

van den Heerik, R. A. M., van Hooijdonk, C. M. J., Burgers, C., \& Steen, G. J. (2017). "Smoking Is Sóóó ... Sandals and White Socks": Co-Creation of a Dutch AntiSmoking Campaign to Change Social Norms. Health Communication, 32(5), 621628. doi: 10.1080/10410236.2016.1168000

Witteborn, S. (2007). The situated expression of Arab collective identities in the United States. Journal of Communication, 57(3), 556575. doi: 10.1111/j.1460-2466.2007.00357.x

Yang, G., \& Calhoun, C. (2007). Media, civil society, and the rise of a green public sphere in China. China Information, (2), 211-236. doi: 10.1177/0920203X07079644 